\title{
DRESS syndrome
}

\author{
Ankush Gupta, ${ }^{1}$ Vijay Kumar Srivastava, ${ }^{1}$ Imran Rizvi, ${ }^{2}$ Atiya Aziz ${ }^{1}$ \\ ${ }^{1}$ Military Hospital, Jodhpur, India \\ 2Jawaharlal Nehru Medical College \& Hospital, AMU, Aligarh, India
}

Correspondence to Dr Ankush Gupta, drankushgupta@gmail.com

\section{DESCRIPTION}

A 16-year-old boy, a known case of epilepsy on oral phenytoin (300 mg/day) and folic acid (5 mg/day) for last 6 weeks, presented with complains of high-grade fever, jaundice and generalised erythematous eruption for 15 days duration. The eruption was maculopapular at onset, which desquamated in the next 3 days and changed to exfoliative dermatitis (figure 1). The patient was on no other medication. He had generalised tender lymphadenopathy, jaundice and tender hepatomegaly. Investigations revealed haemoglobin $12 \mathrm{~g} / \mathrm{dl}$, total leucocyte count $15700 / \mathrm{mm}^{3}$, differential leucocyte count revealed eosinophils $15 \%$, polymorphs $52 \%$, lymphocytes $28 \%$ and monocytes $5 \%$. Serum bilirubin was $7.6 \mathrm{mg} / \mathrm{dl}(0.3-1.0 \mathrm{mg} / \mathrm{dl})$, alanine aminotransferase and aspartate aminotransferase were more than five times the normal. Biopsy of a skin rash revealed spongiosis with intraepidermal vesiculation and patchy exocytosis with no specific pathology in the dermis. All other investigations including septicaemia profile and serology for viral hepatitis were negative. Diagnosis of drug rash with eosinophilia and systemic symptoms (DRESS) syndrome due to phenytoin was made. Phenytoin was discontinued, and patient was started on oral prednisolone at the dose of $1 \mathrm{mg} / \mathrm{kg} /$ day for 2 weeks, which tapered over a period

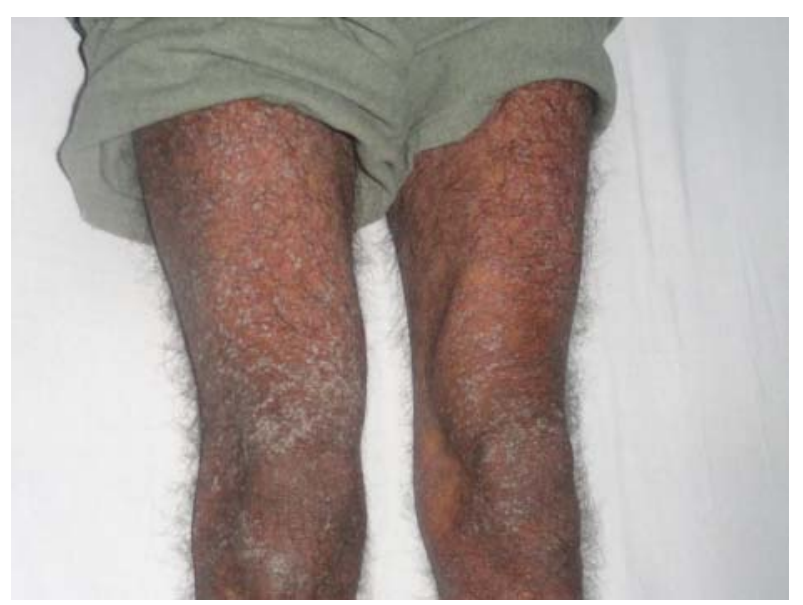

Figure 1 Exfoliative dermatitis over both lower limbs. of next 4 weeks. The patient showed rapid resolution of fever, eosinophilia and progressive improvement in skin rash and liver dysfunction over a period of 3 weeks. Our patient was diagnosed as DRESS syndrome as defined by Bocquet et al. ${ }^{1}$ Clinical features were typical: fever, rash followed by exfoliative dermatitis, lymphadenopathy, eosinophilia and hepatitis. Drugs that commonly cause DRESS syndrome include phenytoin, ${ }^{2}$ phenobarbital, carbamazepine, lamotrigine, minocycline, sulphonamides, sulphasalazine, trimethoprim, allopurinol, abacavir, nevirapine, mexiletine, isoniazid, gold salts, diltiazem, atenolol, captopril, azathioprine and dapsone. DRESS syndrome usually begins several weeks after exposure to the offending drug. The overall mortality in DRESS syndrome is about $10 \% .{ }^{1}$ The most common differential diagnoses for DRESS syndrome are Stevens-Johnson syndrome/toxic epidermal necrolysis, hypereosinphillic syndrome and Kawasaki disease.

\section{Learning points}

- Drug rash with eosinophilia and systemic symptoms (DRESS) syndrome is a life-threatening adverse effect of aromatic anticonvulsants (phenytoin, phenobarbital and carbamazepine).

- Clinicians should have a high index of suspicion for the DRESS syndrome in patients being treated with aromatic anticonvulsants who present with sepsis-like syndrome.

- Management of DRESS syndrome is recognising the presence of this syndrome, immediately stopping the offending drug and use of steroids.

Competing interests None

Patient consent Obtained.

\section{REFERENCES}

1. Bocquet H, Bagot M, Roujeau JC. Drug-induced pseudolymphoma and drug hypersensitivity syndrome (Drug Rash with Eosinophilia and Systemic Symptoms: DRESS). Semin Cutan Med Surg 1996;15:250-7.

2. Allam JP, Paus T, Reichel C, et al. DRESS syndrome associated with carbamazepine and phenytoin. Eur J Dermatol 2004;14:339-42. 


\section{BMJ Case Reports}

This pdf has been created automatically from the final edited text and images.

Copyright 2012 BMJ Publishing Group. All rights reserved. For permission to reuse any of this content visit http://group.bmj.com/group/rights-licensing/permissions.

BMJ Case Report Fellows may re-use this article for personal use and teaching without any further permission.

Please cite this article as follows (you will need to access the article online to obtain the date of publication).

Gupta A, Srivastava VK, Rizvi I, Aziz A. DRESS syndrome. BMJ Case Reports 2012;10.1136/bcr-03-2012-6128, Published XXX

Become a Fellow of BMJ Case Reports today and you can:

- Submit as many cases as you like

- Enjoy fast sympathetic peer review and rapid publication of accepted articles

- Access all the published articles

- Re-use any of the published material for personal use and teaching without further permission

For information on Institutional Fellowships contact consortiasales@bmjgroup.com

Visit casereports.bmj.com for more articles like this and to become a Fellow 